Print ISSN: 2288-4637 / Online ISSN 2288-4645

doi:10.13106/jafeb.2020.vol7.no12.011

\title{
Determinants of Liquidity in Manufacturing Firms*
}

\author{
Thu Minh Thi VU1, Tu Van TRUONG², Dung Thuy DINH ${ }^{3}$
}

Received: September 01, 2020 Revised: October 26, 2020 Accepted: November 05, 2020

\begin{abstract}
This study examines the factors that affect firm's liquidity in manufacturing companies listed in Vietnam. Factors studied include the board size, the board independence, the firm size, the firm age, and its return. We use different metrics to measure firm's solvency status, including the cash ratio, the quick ratio, and the cash conversion cycle. Accordingly, three econometric models are built to test hypotheses proposed by researchers in order to explain the relationship between the five factors above and liquidity's measures. The study used the data set of manufacturing companies listed on the Ho Chi Minh City Stock Exchange in the period from 2015 to 2019. The final sample group comprises 139 firms with 633 observations. The results show that in manufacturing firms, while the cash ratio and the quick ratio are positively associated to the board size, the board independence, and the firm's profitability, the net operating cycle is negatively correlated to the board size, the firm size, the board independence, and the profitability. Therefore, larger firms with larger board size and more independent members can help to improve capital management efficiency.There is no evidence for the relationship between the firm age and solvency measurements, between cash conversion cycle and firm's profitability.
\end{abstract}

Keywords: Firm Solvency, Firm Liquidity, Cash Ratio, Quick Ratio, Net Operating Cycle

JEL Classification Code: G30, G32, M41

\section{Introduction}

There are many aspects to consider when evaluating an effective business. The solvency status reflects quite clearly the quality of business operations in some perspectives. The solvency of an enterprise shows its ability to meet due debts at a defined time. A company with a high solvency position is the one with sufficient financial capacity (cash, cash equivalents and other assets) to ensure the payment of debts

\footnotetext{
*Acknowledgements:

This research is funded by the National Economics University (NEU), Hanoi, Vietnam. The authors thank anonymous referees for their contributions and the NEU for funding this research.

${ }^{1}$ First Author and Corresponding Author. Lecturer, School of Accounting and Auditing, National Economics University, Vietnam [Postal Address: 207 Giai Phong, Dong Tam, Hai Ba Trung, Hanoi, 113068, Vietnam] Email: vuminhthu.neu@gmail.com

${ }^{2}$ Lecturer, School of Accounting and Auditing, National Economics University, Vietnam. Email: truongtu@neu.edu.vn

${ }^{3}$ Lecturer, Faculty of Investment, National Economics University, Vietnam. Email: dtdung@neu.edu.vn

(c) Copyright: The Author(s)

This is an Open Access article distributed under the terms of the Creative Commons Attribution Non-Commercial License (https://creativecommons.org/licenses/by-nc/4.0/) which permits unrestricted non-commercial use, distribution, and reproduction in any medium, provided the original work is properly cited.
}

to individuals and organizations who have relationships with it in the process of production and business activities. On the contrary, when the financial capacity is not enough to cover the debts, enterprises might face the risk of losing their solvency and they might soon fall into bankruptcy.

One of the business's serious problems is that the receivables cannot be recovered and the accounts payable are insolvent. Therefore, enterprises must maintain a reasonable amount of working capital to promptly meet short-term debts to ensure a favorable business operation (Muhammad, Rehman, \& Waqas, 2016). Thus, ensuring solvency can help businesses maintain operating apparatus to continue their investment and development, generating profits in the future.

On the integration process, so far, Vietnam has signed 13 Free Trade Agreements (FTAs), including 7 FTAs signed as ASEAN members and 6 FTAs signed as an independent party, and is currently negotiating 3 FTAs, including the Regional Comprehensive Economic Partnership (RCEP), FTA with the European Free Trade Bloc (EFTA), and the VietnamIsrael FTA. The changing global economic environment has become both an opportunity and a challenge for Vietnamese enterprises, especially those listed on the stock market. Therefore, ensuring good solvency and effective capital management will help to increase the competitiveness of businesses, attract capital in an integrated environment 
as well as help businesses stand firmly in the market. The highlight of the Ho Chi Minh City Stock Exchange (HOSE) is the convergence of large listed companies, with their market capitalization accounting for $79 \%$ of the HOSE's total capitalization and accounting for nearly $74 \%$ of the total market capitalization.

The objective of this study is to identify and analyze the impact of factors on the solvency of enterprises listed on the Ho Chi Minh City Stock Exchange, thereby contributing to improving the effectiveness in cash flow control of businesses.

\section{Literature Review}

\subsection{Firm Solvency}

Solvency of an enterprise is the financial capacity it has to meet the need of debt payment. Financial capacity can exist in the form of cash (cash and cash equivalents), in the form of receivables, or in the form of other assets that can be converted into money such as goods and finished goods.

Solvency analysis evaluates the reasonableness of the fluctuation of receivables and payables, find out the causes and cures of delayed or overdue payments in order to maintain and enhance the company's financial security, ensuring that the company can stay "liquid". According to Hristova, Stevcevska-Srbinoska, Mileva, and Zafirova (2019), liquidity management plays a crucial role as the consequences of the insolvent risk can be very "expensive" and even lead to bankruptcy. As the result, analyzing the solvency of the business is an indispensable tool, contributing to improving the efficiency of capital usage.

- Cash ratio

$$
\begin{aligned}
\text { Cash ratio }= & \text { Cash and cash equivalents/ } \\
& \text { Current liabilities }
\end{aligned}
$$

This indicator reflects the level of cash and cash equivalents to meet the demand to pay off the company's short-term debt. In other words, with the existing amount of cash and cash-equivalent holding, whether or not a company can ensure the ability to cover its debts immediately. This ratio is one common measurement for the company's solvency. This ratio is consider to be the most conservative liquidity ratio because it strictly sticks to the company's most liquid assets (including cash and near-cash equivalents), leaving other resources, including receivables and inventories, out of the equation.

- Quick ratio (Acid test ratio)

$$
\begin{aligned}
& \text { Quick ratio }=(\text { Current Assets }- \text { Inventories }) / \text { Current } \\
& \text { liabilities }
\end{aligned}
$$

Another indicator for the firm's short-term liquidity is the quick ratio. It measures the capacity of companies to pay down coming debts by their liquid assets without having to selling all of inventories stored for operations. This ratio is very useful for both firms and creditors in accessing the financial security of a company. The higher value of quick ratio means better financial health and vice versa.

- Current ratio

Current ratio $=$ Current Assets/ Current Liabilities

This liquidity ratio indicates the ability of firm to pay out short-term obligations which are due within one year by comparing all of current assets to current liabilities. One limitation of this metric is that it may be not productive to compare current ratios between different businesses operating in different industries.

- Net operating cycle (Cash conversion cycle)

Net operating cycle (NOC) or cash conversion cycle measures the length of time between paying out cash for raw materials and other input costs and receiving the cash for goods or services supplied. It measures the duration from the time cash starts to be invested in inventories and other resources to the time cash is released from these items. Commonly, this metric has three components: Inventory holding period (IHP), receivables collection period (RCP), payables payment period (PPP).

$$
N O C=I H P+R C P+P P P(\text { days })
$$

Where:

IHP (Inventory holding Period) = Inventory $x$ 365/ Cost of sales

RCP (Receivable Collection Period) $=$ Receivables $x$

365/ Annual sales revenue

PPP (Payable Payment Period) = Payables $x$ 365/ Annual Purchases

Normally, short inventory holding period, short receivables collection period, and long payable payment period are preferred. This means that the life cycle of cash is shortened and enhanced.

Metrics, including cash ratio, quick ratio, and current ratio, may not provide a comprehensive insight in the business' liquidity status as they all are just a snap-shot at one time for a given period. Therefore, the incorporation of cash conversion cycle can promisingly deliver more 
meaningful inferences for working capital management. Cash conversion cycle was developed by Richards and Laughlin (1980) and they suggested that this measure should be added to the solvency analysis. They also concluded that there is a relationship between the current ratio, the quick ratio and the cash conversion cycle.

All of the above mentioned measures were applied in the majority of researches studying firm's liquidity or working capital. However, while some employed the set of all metrics, many studies focused on just one, two, or three out of these four liquidity ratios. In this study, we use cash ratios, quick ratio, and net operating cycle as the measures for firm's solvency because current ratio, unlike the other ones, lacks specifics. It takes into accounts all of the business's current assets, including those that cannot be easily liquidated. For example, on the surface, two firms that have the same value of current ratio seem to be equivalently liquid. However, the one with more liquid assets, such as with more cash and receivables, will be more solvent because it is more likely to quickly collect cash from receivables than from inventories.

\subsection{Factors Affect Firm's Liquidity}

\subsubsection{Profitability}

While most of the studies have focussed the effect of firm liquidity on firm performance and profitability, there are only a few of them which has studied the reverse impact. The conventional wisdom is that all businesses face a tradeoff between being profitable (providing a return) and being liquid (staying in business). Therefore, it is not a surprise if profitability negatively influences a firm's solvency. Lower liquidity is associated with higher profitability. This result is found in most of the research exploring the relationship and is also in line with the larger bargaining power of firms with higher returns and higher working capital level invested in more profitable projects. Baños-Caballero, García-Teruel, and Martínez-Solano (2010), Petersen and Rajan (1997) argued that firms with higher return receive significantly more credit from their suppliers and they, therefore, expected that firm returns inversely affects its liquidity. Wasiuzzaman (2018) studied solvency of SMEs in Malaysia and concluded that "SMEs with high levels of liquidity do not rely on their profitability to improve their liquidity, instead increased profitability reduces liquidity". Our hypothesis is proposed as follow:

\section{H1: ROA has a negative influence on firm's solvency}

\subsubsection{Board Size}

Board size is one of the important characteristics investigated in the previous researches to have made an impact on the level of working capital investment in firms. Sathyamoorthi, Mbekomize, Mapharing, and Selinkie (2018) contended that the board of directors plays the key role in ensuring the efficiency of company's liquidity management by providing and supervising the firm's working capital policies. They constructed the model to investigate the effect of the board index, represented by board size, executive and non-executive members, male and female members, on each component of cash conversion cycles and this metrics as a whole. The very surprising result is that the combination of board's variables can explain up to $62.5 \%$ in the net operating cycle's fluctuations and among these determinants, board size seems to have the strongest negative influence on the cycle. The same negative correlation was also previously reached by Al-Najjar and Clark (2017), and Zariyawati, Taufiq, Annuar, and Sazali (2010) despite the later' opposite prediction. The expectation proposed in this study is as follow:

\section{H2: Board size has a positive impact on firm's solvency}

\subsubsection{Board Independence}

Normally, in most of the research, board independence is represented by the number of non-executive diretors in the board of a firm. Independent members are invited to join the board in order to oversee management, making sure that managers act for the best interest of the shareholders (Baysinger \& Bulter, 1985; Md. Musfiqur \& Farjana, 2018). Therefore, board independence plays a crucial role in reducing agency conflict and is one of the most important elements of corporate governance mechanism (Vu, Tran, Doan, \& Le, 2020). Studying the data of 127 large Indian firms in the period of 10 years from 2004 to 2013, Goel, Bansal, and Sharma (2015) revealed that an increase in the independence of board leads to adoption of a conservative approach to short-term capital management, which negatively affected working capital efficiency.

However, in another perspective, better corporate governance means more efficient working capital management, leading to the shorter cash conversion cycle. Dittmar and Mahrt-Smith (2007) concluded that corporate governance practises has a substantial impact on the use and the value of cash holdings. They evidently showed that the value of cash is approximately doubled in by well-governed firms compared to firms with poor or weak corporate governance and poorly-governed firms also dissipate cash more quickly and less effficiently. The same finding was reached in the study by Sathyamoorthi, Mbekomize, Mapharing, and Selinkie (2018) as they claimed that the number of non-executive directors has a significantly 
negative correlation with the net operating cycle. Our hypothesis is proposed as follow:

\section{H3: Board independence has a positive impact on firm's} solvency

\subsubsection{Firm Size}

Baños-Caballero, García-Teruel, and Martínez-Solano (2010) examined cash conversion cycle in small and medium-sized firms in Spain and concluded that these firms do have target conversion cycle and they try to shift their current conversion cycle to the target one quickly. They also found that factors including firm age, fixed asset, leverage and profitability are the determinants of the Spanish small and medium-sized enterprises. Especially, small and medium-sized enterprises rely more on shortterm finances because their alternative sources of external finance is very limited, leading to higher payables payment periods compared to the larger firms. Gill and Biger (2013) investigated the relationship between corporate governance practises and the efficiency of working capital management in nearly 200 manufacturing companies on the New York Stock Exchange. They used cash conversion cycle, average cash and current ratio as the proxies for working capital and all of these paremeters are empirically documented to be positively correlated with the firm size. Besides, when breaking down net operating cycle into three components (inventory holding period, receivables collection period, payables payment period), they received the result in line with the research of Baños-Caballero, García-Teruel, and Martínez-Solano (2010) that firm size can help to improve the efficiency of payables payment period management, and which in turn, reduces the length of cash conversion cycle. The posivitive effect of firm size on it's solvency have also been contended in a number of previous reseaches (D'Mello, Krishnaswami, \& Larkin, 2008; Moss \& Stine, 1993; Opler, Pinkowitz, Stulz, \& Williamson, 1999).

\section{H4: Firm size has a positive impact on firm's solvency}

\subsubsection{Firm Age}

Age is measured by the difference between the years studied in the research and the year the company was founded. Mixed results are found on the relationship between firm age and the efficiency of working capital management. BañosCaballero, García-Teruel, and Martínez-Solano (2010), Berger and Udell (1998) demonstrated that older firms have greater investment in working capital and maintain a longer cash conversion cycle because they are easily able to gain access to external financing resouces with lower costs. AlHomaidi, Tabash, Al-Ahdal, Farhan, and Khan (2020) also reached the same conclusion based on a sample of 2154 firms in India from 2010 to 2016.

In contrast, when researchers listed companies in Ghana, Fiador (2016) argued that firm age negatively and significantly affects cash conversion cycle and accounts receivable but positively and insignificantly affects inventory period and payables. He also explained that as companies get older, their cash operating cycyle and receivable collection period improves but their age has no impact on inventories and payables management. It can be inferred that older companies may be more efficient in management of working capital due to the experiences they gain over the years as Wasiuzzaman and Arumugam (2013) explained "As a firm grows older, its relationship with customers and suppliers and its experience in managing its inventory would make it possible to invest less in working capital".

\section{H5: Firm age has an impact on firm's solvency}

\section{Research Method}

To test these hypotheses, the pooled regression model is employed in the study. In addition to the dependent and explanatory variables, the control variables added to the model include: Market-to-book value, leverage, and audit firm. The developed models are as follows:

$$
\begin{aligned}
& \begin{aligned}
Q R= & \beta_{0}+\beta_{1} P_{R O F I T}+\beta_{2} B S_{i t}+\beta_{3} I N D E P_{i t}+\beta_{4} A G E_{i t} \\
& +\beta_{5} F Z+\beta_{6} L E V+\beta_{7} M T B+\beta_{8} A U D I T+e
\end{aligned} \\
& +\beta_{5} F Z_{i t}+\beta_{6} L E V_{i t}+\beta_{7}{ }^{i t} M T B_{i t}+\beta_{8} A U D I T_{i t}+e_{i t} \\
& Q R=\beta_{0}+\beta_{1} P_{R O F I T_{i t}}+\beta_{2} B S_{i t}+\beta_{3} I N D E P_{i t}+\beta_{4} A G E_{i t} \\
& +\beta_{5} F Z_{i t}+\beta_{6} L E V_{i t}+\beta_{7} M T B_{i t}+\beta_{8} A U D I T_{i t}+e_{i t} \\
& N O C=\beta_{0}+\beta_{1} \text { PROFIT }_{i t}+\beta_{2} B S_{i t}+\beta_{3} I N D E P_{i t}+\beta_{4} A G E_{i t} \\
& +\beta_{5} F Z_{i t}+\beta_{6} L E V_{i t}+\beta_{7} M T B_{i t}+\beta_{8} A U D I T_{i t}+e_{i t}
\end{aligned}
$$

Coding and measurement for each variable are shown in Table 1. Accordingly, the measures for firm's liquidity (cash ratio, quick ratio, and net operating cycle) are explained clearly in the literature review.

Growth opportunity is shown in a bunch of studies to have an influence on firm's working capital management (D’Mello, Krishnaswami, \& Larkin, 2008; Opler, Pinkowitz, Stulz, \& Williamson, 1999; Wasiuzzaman, 2018; Zariyawati, Taufiq, Annuar, \& Sazali, 2010). Opler, Pinkowitz, Stulz, and Williamson (1999) found that firms with high level of growth hold more cash or and have high cash ratio. 
Table 1: Variables Codings and Measurements

\begin{tabular}{|l|c|l|}
\hline Name & Code & \multicolumn{1}{|c|}{ Measurement } \\
\hline Cash Ratio & CR & Cash and cash equivalents divided by total current assets \\
\hline Quick Ratio & NOC & $\begin{array}{l}\text { The total value of inventory holding period and receivables collection period } \\
\text { minus payables payment period }\end{array}$ \\
\hline Net Operating Cycle & FS & The total value of the firm's assets \\
\hline Firm Size & AGE & $\begin{array}{l}\text { The difference between the years studied in the research and the year the } \\
\text { company was founded. }\end{array}$ \\
\hline Board Size & BS & The number of members in the board \\
\hline Board Independence & INDEP & The number of non-executive members in the board \\
\hline Return on Assets & ROA & Net income (after tax income) divided by total value of assets \\
\hline Market-to-Book Ratio & MTB & $\begin{array}{l}\text { The market value of the company divided by the total assets. } \\
\text { (Market value = Book value of debts + Market value of owner's equities) }\end{array}$ \\
\hline Leverage & LEV & Long-term debts divided by total assets \\
\hline Audit firm & $\begin{array}{l}\text { AUDIT takes value of 1 if the company is audited by Big4, takes value of } 0 \text { if } \\
\text { it is audited by other auditing companies. }\end{array}$ \\
\hline
\end{tabular}

Leverage could also influence the length of cash conversion cycle, as has been documented in various empirical researches. Pecking order theory supports the negative correlation between leverage and net operating cycle. The theory argued that firms, in general, prefer internal financing over external financing. Firms will take into account debts to finance for their assets only when they run out of internal resources. Therefore, cash operating cycle should be reduced in firms with high level of leverage in order to raise enough capital for their day-to-day operations as well as afford for the debts repayments (Al-Homaidi, Tabash, Al-Ahdal, Farhan, \& Khan, 2020; Baños-Caballero, García-Teruel, \& Martínez-Solano, 2010; Wasiuzzaman \& Arumugam, 2013).

\section{Results}

\subsection{Data Collection and Variable Description}

The study used the data set of manufacturing companies listed on the Ho Chi Minh City Stock Exchange in the period from 2015 to 2019. Data were provided by Vietstock company, a subsidiary of Taiviet Group, a top financial information provider in Vietnam.

Data (including years of operation, total owner's equity, total assets, current assets, cash and cash equivalents, payables, receivables, profit after tax, number of members and non-executive members in the board) are taken from the annual audited financial statements (the balance sheets and the income statements) and the corporate governance reports of those manufacturing listed companies. These data are then employed to calculate metrics: cash ratio, current ratio, net operating cycle, return on assets, market-to-book ratio, leverage, and audit firm. Some observations are also removed as they are invalid and unavailable. Finally, the final sample includes 139 firms with 633 observations coming from the manufacturing industry.

Cash conversion cycle has the length ranging from $-1,883.12$ days to $2,698.27$ days, with an average of 126 days. Generally, a negative net operating cycle is a good sign of working capital management in firms and vice versa.

As shown in Table 2, we can see that there are the big difference between the length of receivables collection days period and that of payables payment period. On an average, a manufacturing firm in Ho Chi Minh City Stock Exchange gives its credit customers 111 days (equivalent to nearly 4 months to pay off their debts while it is offered by the suppliers or creditors for a credit term of just only 46 days. The days of accounts receivables in Vietnamese manufacturing companies is much longer than that in the listed companies in Botswana (10 days) and America (50 days), signifying the inefficient management of receivables (Gill \& Biger, 2013; Sathyamoorthi, Mbekomize, Mapharing, \& Selinkie, 2018). That might be the reason for the high level of debts and liabilities employed by those companies as their mean of debt ratio is at 1.5 . 
Table 2: Statistics Description of Dependent Variables

\begin{tabular}{|l|c|c|c|c|c|c|}
\hline & N & Range & Minimum & Maximum & Mean & Std. Deviation \\
\hline CR & 622 & $0.001-219.83$ & 0.001 & 219.83 & 0.75 & 8.82 \\
\hline QR & 622 & $0.087-612.60$ & 0.087 & 612.69 & 2.50 & 24.58 \\
\hline RCP & 622 & $0.288-729.74$ & 0.288 & 730.02 & 111.44 & 77.67 \\
\hline ICP & 622 & $0.332-448.28$ & 0.332 & 448.28 & 60.22 & 54.73 \\
\hline PDP & 622 & $0.109-2,471.31$ & 0.109 & $2,471.42$ & 45.52 & 103.16 \\
\hline NOC & 622 & $-1,883.12-2,698.27$ & $-1,883.12$ & 815.16 & 125.53 & 124.99 \\
\hline
\end{tabular}

Table 3: Statistics Description of Independent and Control Variables

\begin{tabular}{|l|c|c|c|c|c|c|}
\hline & N & Range & Minimum & Maximum & Mean & Std. Deviation \\
\hline BS & 622 & $3-8$ & 3.00 & 11.00 & 5.77 & 1.30 \\
\hline FS & 622 & $133-78,223$ & 133 & 78,223 & 4,109 & 3.253 \\
\hline INDEP & 622 & $0-10$ & 0.00 & 10.00 & 1.52 \\
\hline AGE & 622 & $1-187$ & 1.00 & -0.25 & 0.918 & 0.108 \\
\hline ROA & 622 & $-0.25-1.169$ & 0.098 & 9.04 & 1.28 & 0.083 \\
\hline MTB & 622 & $0.098-9.04$ & 0.00 & 140.3 & 1.5 & 0.86 \\
\hline LEV & 622 & $0-140.3$ & 0.00 & 1.00 & 0.40 & 5.8 \\
\hline AUDIT & 622 & $0-1$ & & & 0.49 \\
\hline
\end{tabular}

Table 4: Correlation between independent and control variables

\begin{tabular}{|c|c|c|c|c|c|c|c|c|c|}
\hline & BZ & $\mathbf{F Z}$ & DEP & AGE & ROA & MTB & LEV & AUDIT & VIF \\
\hline BS & 1 & & & & & & & & 1.58 \\
\hline FS & $.196^{* *}$ & 1 & & & & & & & 1.21 \\
\hline INDEP & $.389^{* *}$ & $.110^{* *}$ & 1 & & & & & & 1.67 \\
\hline AGE & $.094^{*}$ & $.198^{* *}$ & $.359^{* *}$ & 1 & & & & & 1.09 \\
\hline ROA & $.155^{\star *}$ & -0.046 & $.141^{* *}$ & $.098^{*}$ & 1 & & & & 1.44 \\
\hline MTB & $.139^{* *}$ & -0.039 & $.237^{* *}$ & $.192^{* *}$ & $.553^{* *}$ & 1 & & & 1.52 \\
\hline LEV & -0.049 & 0.001 & -0.07 & -0.063 & $-.231^{* *}$ & -0.03 & 1 & & 1.08 \\
\hline AUDIT & $.249^{* *}$ & $.231^{* *}$ & $.263^{\star *}$ & $.109^{\star *}$ & $.145^{\star *}$ & $.275^{* *}$ & 0.035 & 1 & 1.29 \\
\hline Observations & 622 & 622 & 622 & 622 & 622 & 622 & 622 & 622 & \\
\hline
\end{tabular}


It can be concluded form the Table 4 that the set of data collected from sampled firms has no problem of severe multi-collinearity.

\subsection{Results and Discussion}

The Table 5 shows the results under linear regression models.

According to the results shown above, the Models (8) (9) (10) can be re-written as follows:

$$
\begin{aligned}
C R= & 0.328+0.683 \mathrm{PROFIT}_{i t}+0.045 \mathrm{BS}_{i t} \\
& +0.045 \mathrm{INDEP}_{i t}+0.003 \mathrm{AGE}_{i t} \\
& -(3.16 E-06) \mathrm{FS}_{i t}-0.007 \mathrm{LEV}_{i t}-0.055 \mathrm{MTB}_{i t} \\
& +0.059 \mathrm{AUDIT}_{i t} \\
Q R= & 1.763+1.14 \mathrm{PROFIT}_{i t}+0.075 \mathrm{BS}_{i t}+0.073 \\
& I N D E P_{i t}+0.004 \mathrm{AGE}_{i t}-(1.76 E-06) \mathrm{FS}_{i t} \\
& -0.025 \mathrm{LEV}_{i t}-0.127 \mathrm{MTB}_{i t}-0.221 \mathrm{AUDIT} \mathrm{T}_{i t} \\
\text { NOC }= & 150.56-229.91 \mathrm{PROFIT}_{i t}-16.961 \mathrm{BS}_{i t} \\
& -18.375 \mathrm{INDEP}_{i t}+0.618 \mathrm{AGE} \mathrm{Fi}_{i t}-0.001 \mathrm{FS}_{i t} \\
& +1.759 \mathrm{LEV}_{i t}-4.419 \mathrm{MTB}_{i t} \\
& -4.125 \mathrm{AUDIT}_{i t}
\end{aligned}
$$

Overall, board size is found to have a positive impact on cash ratio, quick ratio, but negative impact on cash conversion cycle. These results for board size are all significant. While the influencing directions of firm size on liquidity metrics are all negative, only effect on the net operating cycle is significant. These evidence indicate that larger firms with more members in their board can help to improve capital management efficiency.

Similarly, cash ratio and quick ratio are positively correlated to board independence, while cash conversion cycle is negatively associated to board independence. The appearance of independent members in the board decreases the length of the cash cycle, therefore, enhancing the liquidity status of the business. This finding provides more support to the argument that firms with good corporate governance practises have a positive impact on their liquidity management.

Profitability (Return on assets) is revealed to positively affect cash ratio and quick ratio, but have no impact on firm's working capital cycle. This may imply that more profitable firms have better positions of cash holdings against their current debts.

The research does not find the evidence for the relationship between firm age and solvency measurements.

Table 5: Regression Results

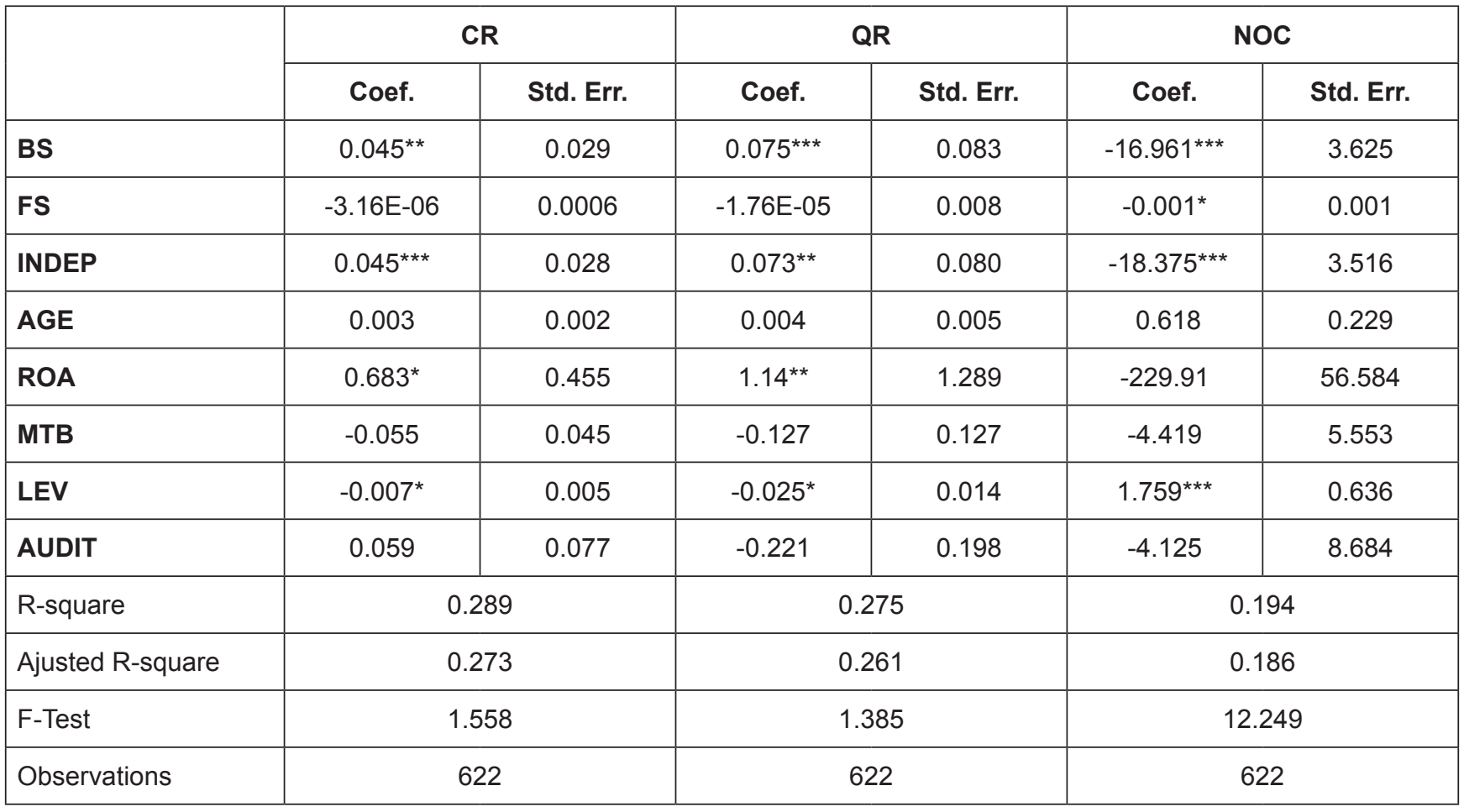




\section{Conclusion}

In the current economic conditions, the fluctuations in the economic market brings both opportunities and challenges for all companies. To make good decisions in a business, companies cannot help but pay attention to the financial issues, especially the liquidity or solvency. The bankruptcy law under the market mechanism stipulates that enterprises may be declared bankrupt at the request of creditors when their assets cannot compensate for their debts. This has created challenging problems for management as they always have to face and deal with a trade-off between profitability and liquidity. Managers must make the most of suppliers' finance, debt finance, but at the same time, they must be careful and should not lose their control over debts which may lead to insolvency. Therefore, carefully researching and analyzing the operating situation and making a reasonable policy in solvency management are very important tasks for each business to ensure its benefits and reputation. As a result, determining the factors affecting the solvency will help firms build their reasonable working capital level in business, thereby developing profitable production and business activities.

\section{References}

Al-Homaidi, E. A., Tabash, M. I., Al-Ahdal, W. M., Farhan, N. H. S., \& Khan, S. H. (2020). The Liquidity of Indian Firms: Empirical Evidence of 2154 Firms. Journal of Asian Finance, Economics, and Business, 7(1), 19-27. https://doi.org/10.13106/jafeb.2020. vol7.no1.19

Al-Najjar, B., \& Clark, E. (2017). Corporate governance and cash holdings in MENA: Evidence from internal and external governance practices. Research in International Business and Finance, 39, 1-12. https://doi.org/10.1016/j.ribaf.2016.07.030

Baños-Caballero, S., García-Teruel, P., \& Martínez-Solano, P. (2010). Working capital management in SMEs. Accounting and Finance, 50, 511-527. https://doi.org/10.1111/j.1467629X.2009.00331.x

Baysinger, B. D., \& Butler, H, N. (1985). Corporate Governance and the Board of Directors: Performance Effects of Changes in Board Composition. Journal of Law, Economics \& Organization, 1(1), 101-125. https://doi.org/10.1093/ oxfordjournals.jleo.a036883

Berger, A. N., \& Udell, G. F. (1998). The economics of small business: the roles of private equity and debt markets in the financial growth cycle. Journal of Banking and Finance, 22, 613-673. https://doi.org/10.1016/S0378-4266(98)00038-7

D’Mello, R., Krishnaswami, S., \& Larkin, P. J. (2008). Determinants of corporate cash holdings: Evidence from spinoffs. Journal of Banking and Finance, 32, 1209-1220. http:// dx.doi.org/10.1016/j.jbankfin.2007.10.005
Dittmar, A., \& Mahrt-Smith, J. (2007). Corporate governance and the value of cash holdings. Journal of Financial Economics, 83(3), 599-634. https://doi.org/10.1016/j.jfineco. 2005.12.006

Fiador, V. (2016). Does Corporate Governance Influence the Efficiency of Working Capital Management of Listed Firms: Evidence from Ghana. African Journal of Economic and Management Studies, 7(4), 482-496. https://doi.org/10.1108/ AJEMS-08-2015-0096

Gill, A., \& Biger, N. (2013). The impact of corporate governance on working capital management efficiency of American manufacturing firms. Managerial Finance, 39, 116-132. https:// doi.org/10.1108/03074351311293981

Goel, U., Bansal, N., \& Sharma, A. (2015). Impact of Corporate Governance Practices on working Capital Management Efficiency: A Structural Equation Modelling Approach. Indian Journal of Finance, 9(1), 38-48. https://doi.org/10.17010/ $\mathrm{ijf} / 2015 / \mathrm{v} 9 \mathrm{i1} / 71534$

Hristova, S., Stevcevska-Srbinoska, D., Mileva, I., \& Zafirova, A. (2019). Trade-Off Between Liquidity and Profitability: An Empirical Study of Pharmaceutical Sector in the Republic of North Macedonia. Timisoara Journal of Economics and Business, 12, 127-148. https://doi.org/10.2478/tjeb-2019-0007

Moss, J. D., \& Stine, B. (1993). Cash Conversion Cycle and Firm Size: A Study of Retail Firms. Managerial Finance, 19(8), 25-34. http://dx.doi.org/10.1108/eb013739

Md. Musfiqur, R., \& Farjana N. S. (2018). Efficiency of Board Composition on Firm Performance: Empirical Evidence from listed Manufacturing Firms of Bangladesh. Journal of Asian Finance, Economics and Business, 5(2), 53-61. https://doi. org/10.13106/jafeb.2018.vol5.no2.53

Muhammad, H., Rehman, A. U., \& Waqas, M. (2016). The Relationship between Working Capital Management and Profitability: A Case Study of Tobacco Industry of Pakistan. Journal of Asian Finance, Economics, and Business, 3(2), 1320. https://doi.org/10.13106/jafeb.2016.vol3.no2.13.

Opler, T., Pinkowitz, L., Stulz, R., \& Williamson, R. (1999). The determinants and implications of corporate cash holdings. Journal of Financial Economics, 52(1), 3-46. http://dx.doi. org/10.1016/S0304-405X(99)00003-3

Petersen, M., \& Rajan, R. (1997). Trade Credit: Theories and Evidence. Review of Financial Studies, 10, 661-691. https:// doi.org/10.1093/rfs/10.3.661

Richards, D. V., \& Laughlin, J. E. (1980). A Cash Conversion Cycle Approach to Liquidity Analysis. Financial Management, 9(1), 32. https://doi.org/10.2307/3665310

Sathyamoorthi, C. R., Mbekomize, C., Mapharing, M., \& Selinkie, P. (2018). The Impact of Corporate Governance on Working Capital Management Efficiency: Evidence from the Listed Companies in the Consumer Services Sector in Botswana. International Journal of Economics and Finance, 10, 135. https://doi.org/10.5539/ijef.v10n12p135 
Vu, T.M.T., Tran, C. Q., Doan, D. T., \& Le, T.N.(2020). Determinants of Capital Structure: The Case in Vietnam. Journal of Asian Finance, Economics, And Business, 7(9), 159-168. https://doi. org/10.13106/jafeb.2020.vol7.no9.159

Wasiuzzaman, S. (2018). Determinants of Liquidity in Malaysian SMEs: A quantile regression approach. International Journal of Productivity and Performance Management, 67, 1566-1584. https://doi.org/10.1108/IJPPM-12-2017-0354
Wasiuzzaman, S., \& Arumugam, V. C. (2013). Determinants of Working Capital Investment: A Study of Malaysian Public Listed Firms. Australasian Accounting, Business and Finance Journal, 7(2), 63-83. https://doi.org/10.14453/aabfj.v7i2.5

Zariyawati, M. A., Taufiq, H., Annuar, M. N. \& Sazali, A. (2010). Determinants of Working Capital Management: Evidence from Malaysia. Proceedings of the 2010 International Conference, Dubai, UAE, 18 - 20 June 2010, IEEE Computer Society Press, 190-194. https://doi.org/10.1109/ICFTE.2010.5499399 